\title{
Transcriptional Regulation of Components of the Type III Secretion System and Effectors in Pseudomonas syringae pv. phaseolicola
}

\author{
R. Thwaites, ${ }^{1}$ P. D. Spanu, ${ }^{2}$ N. J. Panopoulos, ${ }^{3}$ C. Stevens,${ }^{4}$ and J. W. Mansfield ${ }^{1}$ \\ ${ }^{1}$ Department of Agricultural Sciences, Imperial College London, Wye Campus, Wye, Ashford Kent TN25 5AH, U.K.; \\ ${ }^{2}$ Department of Biological Sciences, Imperial College London SW7 2AZ, U.K.; ${ }^{3}$ Institute of Molecular Biology and \\ Biotechnology, University of Crete, PO Box 1527, GR-711 10 Iraklio, Crete, Greece; ${ }^{4}$ International Rice Research Institute, \\ Dhaka Office, GPO Box 64, Ramna, Dhaka 1000, Bangladesh
}

Submitted 2 April 2004. Accepted 29 June 2004.

\begin{abstract}
Quantitative real-time polymerase chain reaction was used with specific TaqMan probes to examine transcription of selected hrp and effector genes in Pseudomonas syringae pv. phaseolicola strains 1448A (race 6) and 1449B (race 7). Transcripts examined were from genes encoding the regulators $h r p R$ and $h r p L$, core structural components of the type III secretion system (TTSS) hrcC, hrcJ, hrcN, hrcU, and $h r p A$; the first open-reading frame of each $h r p$ operon, including $h r p F$, hrpJ, hrpP, and $h r p Y$; and also secreted effectors $h r p Z$, avrPphE, avrPphF, and virPphA. All genes were induced by incubation in a minimal medium and showed patterns of expression indicating regulation by HrpRS and HrpL. Basal mRNA levels and the timing of accumulation of transcripts after induction differed significantly, suggesting the operation of additional regulatory elements. However, no clear transcriptional hierarchy emerged to explain the ordered construction of the TTSS. Quantitative analysis confirmed that the rates and levels of transcript accumulation within the first $2 \mathrm{~h}$ after inoculation were considerably higher in planta than in vitro, and indicated that plant cell wall contact may enhance transcription of TTSS and effector genes in $P$. syringae pv. phaseolicola. The low-abundance hrcU mRNA had a halflife of $16.5 \mathrm{~min}$, whereas other transcripts had half-lives between 3 and $8 \mathrm{~min}$.
\end{abstract}

Additional keywords: hrc, pathogenicity, RNA stability.

Many bacterial pathogens of animals and plants construct a remarkable piece of cellular architecture, the type III secretion system (TTSS), which is exquisitely designed to deliver proteins into host cells (Blocker et al. 2003; Cornelis and Van Gijsegem 2000; Jin et al. 2003). In Pseudomonas syringae, as in other plant pathogens, genes encoding the TTSS are clustered into a pathogenicity island. Genetic dissection of the TTSS in P. syringae began with the discovery of so called $h r p$ mutants of the bean pathogen $P$. syringae pv. phaseolicola which lost the ability to elicit a hypersensitive resistant reaction (HR) in nonhost plants such as tobacco and also lost patho-

Corresponding author: J. W. Mansfield; Telephone: 020 75942773; Fax: 020 75942669; E-mail: j.mansfield@ imperial.ac.uk

* The $\boldsymbol{e}$-Xtra logo stands for "electronic extra" and indicates the HTML abstract available on-line contains four supplemental figures not included in the print edition. genicity to bean (Lindgren 1997; Lindgren et al. 1986; Rahme et al. 1992). Further research revealed clusters of hrp genes, some of which encoded proteins conserved among plant and animal pathogens and therefore designated hrc (hrp-conserved). Nomenclature of the conserved components of the TTSS in plant pathogens is based on the identity of their functional homologues in Yersinia spp. (Bogdanove et al. 1996). An additional and exceptional component of the injectosome in plant pathogens, including species of Pseudomonas, Xanthomonas, Erwinia, and Ralstonia, is the Hrp pilus which is an extension of the extracellular domain of the TTSS (Cornelis and Van Gijsegem 2000). In pathovars of P. syringae, the Hrp pilus is composed of subunits of HrpA protein. Polar extension of the appendage through the distal addition of HrpA subunits to the filament tip allows the pilus to penetrate the plant cell wall (Jin and He 2001; Li et al. 2002). The hrp genes encode not only structural components of the TTSS but also secreted proteins such as HrpZ which may be similar in function to the translocon components YopB/IpaB/EspD and Yop/D/IpaC/EspB of the animal pathogens Yersinia spp., Salmonella spp., and enteropathogenic Escherichia coli (Blocker et al. 2003; Lee et al. 2001).

DNA sequence analysis and northern hybridization experiments have shown that genes within the hrp cluster of pathovars of $P$. syringae are organized into at least six operons (Lindgren 1997). Comparison between $P$. syringae pv. phaseolicola and related pathovars such as syringae and tomato have indicated some differences in operon structure. For example, in $P$. syringae pv. phaseolicola, hrpA and hrpZ are members of separate transcriptional units, but they are both within a single operon in P. syringae pv. syringae (Lee et al. 2001; Preston et al. 1995). Reporter gene constructs have been used to reveal regulatory networks controlling expression of genes encoding the TTSS in plant pathogens (Huynh et al. 1989; Rahme et al. 1992). In P. syringae, an important regulatory cascade has been identified involving three positive regulators: HrpR and HrpS (transcribed as a single operon) and HrpL. HrpR and HrpS interact directly and, with the sigma factor $\sigma^{54}$, activate expression of $h r p L$ (Grimm et al. 1995; Xiao and Hutcheson 1994). Other hrp and hrc genes are thought to be regulated primarily by HrpL. A characteristic promoter motif, the "hrp box", has been identified upstream of genes regulated by HrpL which include not only TTSS components but also genes encoding effector proteins which are delivered into the plant cell cytoplasm (Collmer et al. 2002). Basal levels of hrp and effector gene expression have been reported to be very low in rich media but transcript accu- 
mulation is induced in minimal medium which is thought to replicate conditions within the intercellular spaces of plant hosts (Huynh et al. 1989; van Gijsegem 1997). Contact with host cells is recognized as an essential activator of the TTSS in animal pathogens, including species of Yersinia, Salmonella, and Shigella (Blocker et al. 2003). Experiments using plant cell suspension cultures have also demonstrated an important role for contact in the expression of hrp genes in the vascular wilt pathogen Ralstonia Solanacearum (Aldon et al. 2000). However, unlike $P$. syringae, $R$. solanacearum utilizes an AraC-based regulation system (Marenda et al. 1998).

Building the TTSS and the coordination of secretion of effector proteins must require a remarkable degree of finetuned expression of approximately 25 proteins which may contribute to the injectosome and approximately 30 effectors predicted to have key roles in virulence in $P$. syringae (Collmer et al. 2002). The structural and functional similarity between the Hrp-based TTSS and the flagellum has been described often (Blocker et al. 2003; He 1997). The regulation of flagellum biosynthesis is governed by a highly complex network, linking synthesis and assembly of the flagellar apparatus and employing both transcriptional and post-transcriptional regulation (Soutourina and Bertin 2003).

We have examined the transcription of a selection of $h r c$ and $h r p$ genes, including the first members of each $h r p$ operon in $P$. syringae pv. phaseolicola, and also three effectors, avrPphE, avrPphF, and virPphA (Jackson et al. 1999; Mansfield et al. 1994; Tsiamis et al. 2000). Genes examined here include those encoding key structural components $h r c C$ (the outer membrane "secretin"), $h r c U$ (located to the inner membrane), hrcJ (spanning the inner and outer membrane), and $h r c N$ (inner membrane associated ATPase), and the secreted proteins the pilin subunit $h r p A$ and putative translocon component $h r p Z$. Previous analysis of gene expression in $P$. syringae has used reporter genes or microarrays, neither of which allows unambiguous quantitative measurement of transcript levels (Huynh et al. 1989; Rahme et al. 1992; Zwiesler-Vollick et al. 2002). We have developed methods to quantify RNA levels in vitro and in the plant, in comparison with the constitutively expressed 16S RNA gene. We chose to use TaqMan real-time polymerase chain reaction (PCR) assays which utilize the exonuclease activity of $T a q$ polymerase to release a fluorophore from a specific nucleotide probe. The high level of sensitivity and specificity afforded by the TaqMan probe provides the most accurate method of mRNA quantification (Bustin 2002). Our hypothesis was that the direct, quantitative analysis of transcript abundance might reveal a transcriptional hierarchy similar to that observed during construction of flagella.

\section{RESULTS}

\section{Expression in vitro.}

The locations of the genes examined within the hrp cluster are shown in Figure 1. Preliminary experiments compared expression levels in race 6 and race 7 using template cDNA generated either with primers designed to be specific for each gene or with random oligonucleotides. No differences were observed and, therefore, random oligonucleotides were used for synthesis of all cDNAs in the experiments described. Thus, we were able to examine all transcripts in the same cDNA preparation.

Basal levels of transcription determined directly from bacteria grown in Luria-Bertani (LB) broth or after the initial washing in $10 \mathrm{mM} \mathrm{MgCl}_{2}$ (Table 1) were considerably higher for hrpA and virPphA (approximately $10^{-7}$ per $16 \mathrm{~S}$ transcript in washed cells) compared with hrpR $\left(10^{-8}\right)$ and other genes (basal levels $10^{-9}$ to $10^{-10}$ per $16 \mathrm{~S}$ transcript). Transfer of the wild-type strains to minimal medium led to rapid induction of expression of all genes. Detailed time course data obtained with wild-type race 6 for the regulators $h r p R$ and $h r p L$, the highly expressed pilus subunit-encoding $h r p A$, and $h r p P$ as an example of a typical transcript, are given in Figure 2. There were significant differences in the rates of accumulation of individual RNAs. Most striking was the increase in $h r p R$ mRNA within 5 min of induction and, by $20 \mathrm{~min}$, this transcript had increased 10-fold. Other transcripts accumulated more gradually, significant increases being recorded after 10 $\min$ for $h r p L, h r p A$, and $h r p Z$, and $20 \mathrm{~min}$ for $h r c C$, $h r c J$, $h r p F, h r p P, h r p Y$, and the effector avrPphE. Despite the higher constitutive levels of virPphA RNA, clear induction of this transcript was apparent only after $40 \mathrm{~min}$, when increases in $h r p J$ and $h r c N$ RNAs also were recorded. The $h r c U$ transcript increased significantly only after $80 \mathrm{~min}$. Differences in transcript abundance were apparent after induction for $120 \mathrm{~min}$;

Table 1. Induction of transcripts of Pseudomonas syringae pv. phaseolicola race 6 in vitro ${ }^{\mathrm{a}}$

\begin{tabular}{lccc}
\hline & \multicolumn{2}{c}{ No. of transcripts relative to $\mathbf{1 6 S}^{\mathbf{b}}$} & \\
\cline { 2 - 3 } Transcript & Basal (time 0) $^{\mathbf{c}}$ & $\mathbf{1 2 0 ~ \mathbf { ~ m i n }}$ & Fold increase \\
\hline virPphA & $3.7 \times 10^{-7}$ & $6.4 \times 10^{-6}$ & 17 \\
hrpA & $1.0 \times 10^{-7}$ & $4.6 \times 10^{-5}$ & 459 \\
hrpR & $1.5 \times 10^{-8}$ & $1.8 \times 10^{-7}$ & 12 \\
hrcN & $8.6 \times 10^{-9}$ & $1.1 \times 10^{-6}$ & 125 \\
hrpF & $1.9 \times 10^{-9}$ & $1.4 \times 10^{-6}$ & 740 \\
hrpL & $1.1 \times 10^{-9}$ & $6.2 \times 10^{-7}$ & 587 \\
hrpZ & $1.0 \times 10^{-9}$ & $3.2 \times 10^{-6}$ & 3,074 \\
hrpJ & $7.9 \times 10^{-10}$ & $1.5 \times 10^{-7}$ & 188 \\
hrpY & $6.9 \times 10^{-10}$ & $1.3 \times 10^{-6}$ & 1,857 \\
hrpP & $5.8 \times 10^{-10}$ & $1.1 \times 10^{-6}$ & 1,905 \\
avrPphE & $5.7 \times 10^{-10}$ & $5.2 \times 10^{-7}$ & 921 \\
hrcU & $2.7 \times 10^{-10}$ & $6.3 \times 10^{-9}$ & 23 \\
hrcJ & $2.1 \times 10^{-10}$ & $1.9 \times 10^{-7}$ & 922 \\
hrcC & $1.9 \times 10^{-10}$ & $2.4 \times 10^{-7}$ & 1,299 \\
\hline
\end{tabular}

${ }^{a}$ Levels are compared before and after incubation for $120 \mathrm{~min}$ in minimal medium.

${ }^{\mathrm{b}}$ Data are means compiled from two repeated experiments using duplicate analyses at each time point.

${ }^{c}$ Basal levels recorded after washing bacteria in $10 \mathrm{mM} \mathrm{MgCl}$ before suspension in minimal medium.

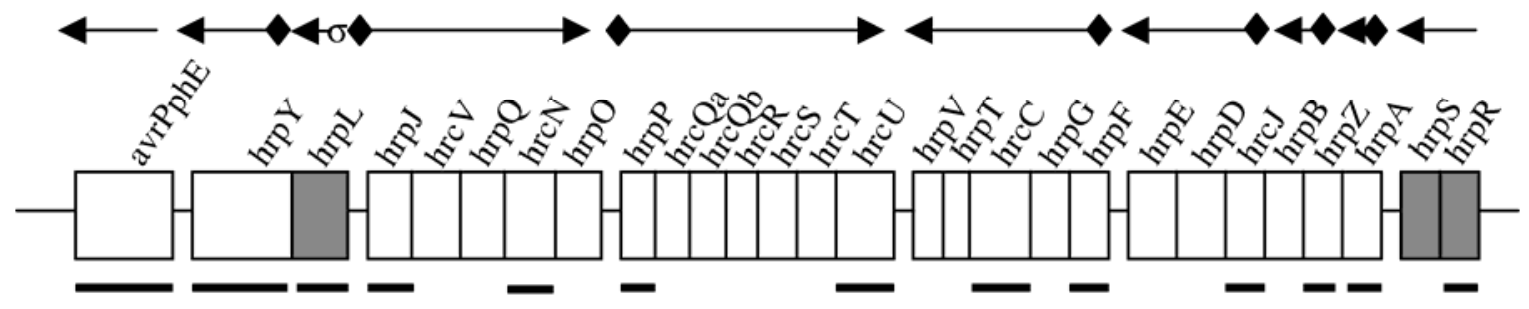

Fig. 1. The hrp cluster of Pseudomonas syringae pv. phaseolicola. Genes are organized in nine operons (indicated by arrows); $\bullet$ indicates an hrp box and $\sigma$ is a $\sigma^{54}$-dependent promoter. Genes with major regulatory functions are shaded. Open reading frames selected for expression analysis are indicated by bold underlining. DNA sequences were obtained from GenBank, accession numbers U16817, AJ430232, AF043444, AF268940, X77638, AY505348, and AY505349. 
the levels of expression relative to $16 \mathrm{~S}$ RNA and fold induction over basal levels are recorded for all genes in Table 1.

Examples of gene expression data recorded in vitro for an hrpL Tn3gus insertion mutant of race 6 are compared with results for the wild-type strain in Figure 2. In the hrpL mutant, only $h r p R$ was induced during incubation in minimal media. However, abundance of the $h r p R$ transcript throughout the time course was approximately half that recorded in wild-type rifampicin-resistant 1448A.

RNA of the effector $a v r P p h F$ was not detected in race 6; however, in race 7 , it accumulated in a pattern very similar to avrPphE, reaching $5.0 \times 10^{-7}$ copies relative to $16 \mathrm{~S}$ after 120 min. The patterns of accumulation of other transcripts in race 7 (data not shown) also were similar to those presented for race 6 (Fig. 2).

\section{Expression in leaves.}

The sensitivity of quantification afforded by the TaqMan system allowed gene expression to be examined in small amounts of inoculated leaf tissue. Transcript levels of race 6 (1448A) were examined for up to $24 \mathrm{~h}$ after injection of bacterial suspension into the intercellular spaces of unifoliate bean leaves (Fig. 3). In the plant, increases in expression were notably delayed compared with those found in minimal medium. However, after $120 \mathrm{~min}$, transcript levels for all genes examined were greatly increased in leaves and were, on average,
$8.6 \times$ higher than recorded in vitro. Enhanced accumulation of the regulators $h r p L$ and $h r p R$ was particularly striking, being over $15 \times$ higher in planta than in vitro. The same orders of abundance and onset of accumulation, with induction of the regulator $h r p R$ being most rapid, were noted in the plant as in minimal medium. The times after incubation when twofold increases in mRNA over basal levels were recorded are compared in Table 2.

In leaves, transcripts increased for all genes except the regulator $h r p R$ between 120 and $240 \mathrm{~min}$. A striking reduction in RNA levels was found after $24 \mathrm{~h}$, as the colonies of the pathogen expanded within the intercellular spaces and bacterial numbers had increased 50-fold as determined from levels of 16S RNA within the susceptible cv. Canadian Wonder.

Extraction procedures were modified in an attempt to examine expression of transcripts in bacteria (race 6) in contact with the plant cell walls after 120 min. Following homogenization, cell wall debris and attached bacteria were recovered on $10-\mu \mathrm{m}$ filters. Unattached bacteria were released and passed through the filter by repeated washing. Analysis of 16S RNA levels indicated that very few bacteria remained attached to the cell wall debris and consistent, significant detection of RNA was possible only for the most abundant transcripts, $h r p A, h r p Z$, and virPphA. Expression levels were significantly higher in the bacteria attached to cell wall debris. The mean $( \pm$ standard error of the mean) ratios for RNA levels in attached/unattached
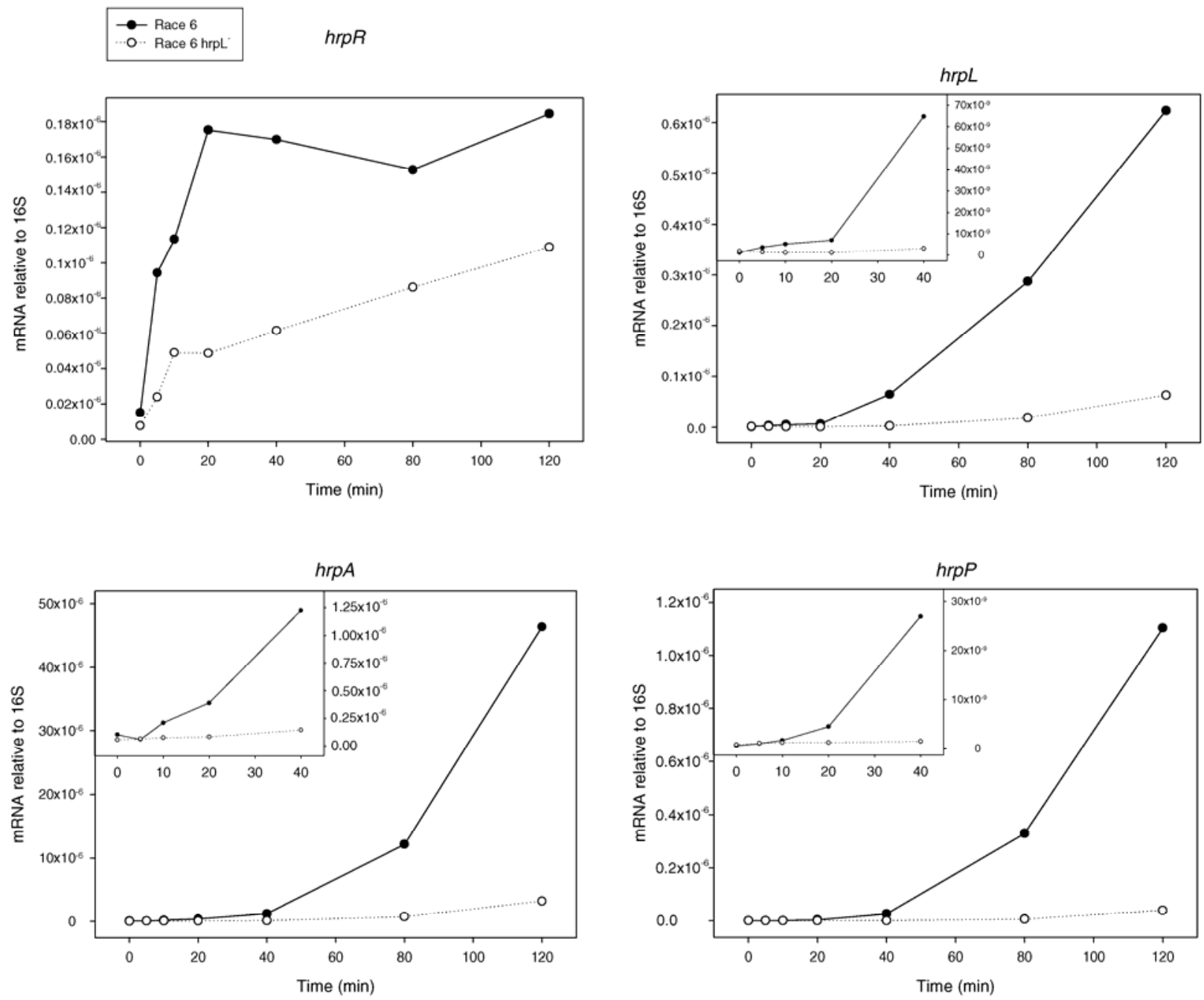

Fig. 2. Induction of $h r p$ genes in Pseudomonas syringae pv. phaseolicola race 6 strain 1448A (rifampicin-resistant wild-type) and $h r p L^{-}$strains after transfer to minimal medium (in vitro). Inserts with expanded scales are included to show early changes in transcript abundance up to 40 min after incubation began. Data for other genes examined are provided as supplemental material; results are from duplicate analyses. 
bacteria recorded from three experiments were $1.7 \pm 0.64,2.3$ \pm 0.4 , and $2.4 \pm 0.65$ for $h r p A$, hrpZ, and virPphA, respectively. Therefore, in addition to the overall increase in expression detected in the plant, there was an indication of enhanced upregulation in bacteria in contact with plant cell walls.

\section{RNA stability in vitro.}

A rifampicin-sensitive strain of race 7 (1449B) was used to examine the possible contribution of RNA stability to expression of TTSS components and effectors. Time course analysis up to $120 \mathrm{~min}$ after incubation in minimal media confirmed the established patterns of expression in this experiment as recorded for representative transcripts $h r p A, h r c J, h r p R$, and hrpZ. After $120 \mathrm{~min}$, rifampicin was added to the incubation medium (final concentration $200 \mu \mathrm{g} \mathrm{ml}^{-1}$ ), and transcript levels of all target genes subsequently were determined for up to 60 min. Data obtained for selected mRNAs are given in Figure 4. An initial increase in signal was observed for most genes after addition of antibiotic, but transcript decay was subsequently evident for all genes by 5 min after addition of the RNA polymerase inhibitor. Levels dropped rapidly and were undetectable for most genes after $20 \mathrm{~min}$, exceptions being the more abundant species (such as $h r p A$ and $h r p Z$ ) and the comparatively long-lived transcript for $h r c U$. Half-lives determined for each transcript were as follows: $h r p J, 3 \mathrm{~min} ; h r c N, 4 \mathrm{~min} ; h r c J$ and avrPphE, $4.5 \mathrm{~min}$; $h r c C$, hrpY, and avrPphF, $5.5 \mathrm{~min}$; hrpP and virPphA, $6 \mathrm{~min}$; hrpL, hrpR, and hrpZ, $6.5 \mathrm{~min}$; $h r p F, 7.5 \mathrm{~min}$; $h r p A, 8 \mathrm{~min}$; and $h r c U, 16.5 \mathrm{~min}$. No signifi- cant reduction in $16 \mathrm{~S}$ RNA was recorded during the 60-min incubation.

\section{DISCUSSION}

The exceptionally rapid induction of $h r p R$ both in vitro and in planta is consistent with its proposed role as a key regulator in $P$. syringae (Xiao and Hutcheson 1994). Interestingly, the intermediate role of $\mathrm{HrpL}$ in the regulon could not be inferred directly from the timing of accumulation of $h r p L$ RNA because other transcripts, putatively regulated by $\mathrm{HrpL}$, increased at approximately the same time. Nevertheless, the absence of induced expression of effector and $h r p$ genes (except $h r p R$ ) in the $h r p L$ mutant confirmed the importance of HrpL in the regulatory cascade. The rapid induction of $h r p R$ observed here has not been reported for other pathovars of $P$. syringae or strains of $P$. syringae pv. phaseolicola in which promoter fusions were used to assess expression (Bretz et al. 2002; Rahme et al. 1992). We also found that $h r p R$ was at least partially regulated by HrpL, indicating the existence of a previously unrecognized autoregulatory loop in what has come to be considered a unidirectional expression cascade from $h r p R S \rightarrow h r p L \rightarrow$ hrp and effector genes (Xiao and Hutcheson 1994). However, autoregulation has been proposed in the similar cascade described in Erwinia herbicola pv. gypsophilae (Nizan-Koren et al. 2003). Regulatory controls, in addition to HrpL, allowing more gene-specific fine tuning of transcription were also indicated by the clear differences between mRNA levels recorded in P. syringae pv. phaseolicola. In
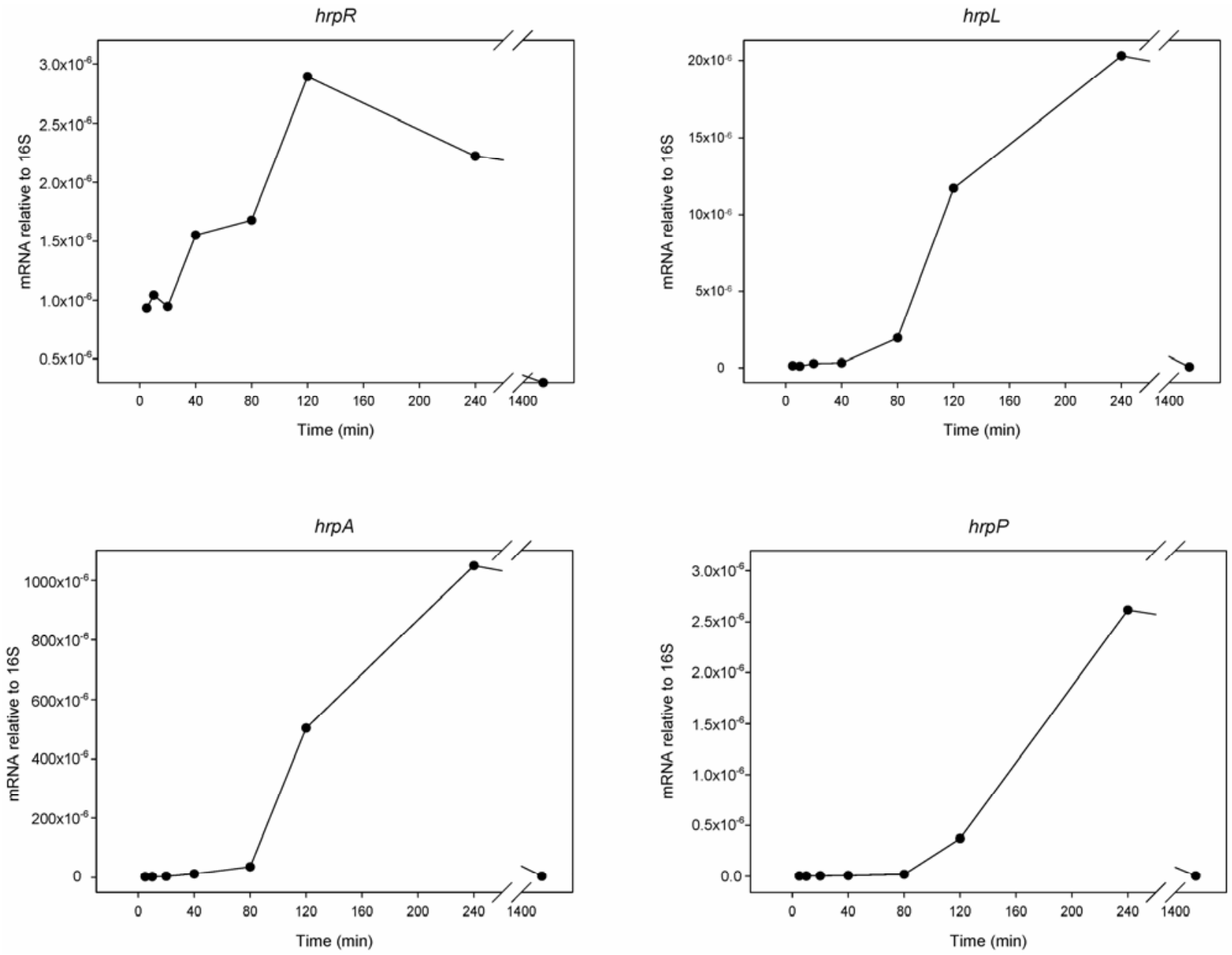

Fig. 3. Induction of $h r p$ genes in Pseudomonas syringae pv. phaseolicola race 6 strain 1448A (rifampicin-resistant wild-type) in leaves of the susceptible bean cv. Canadian Wonder. Data for other genes examined are provided as supplemental material; results are from duplicate analyses. 
particular, basal levels of hrpA and virPphA transcripts were at least 10-fold higher than those of other genes examined in either wild-type or $h r p L$ background. The other gene to reach high mRNA levels was $h r p Z$ which encodes the readily secreted "harpin" protein (Lee et al. 2001).

Table 2. Accumulation of transcripts in vitro and in planta by Pseudomonas syringae pv. phaseolicola 1448A (race 6) ${ }^{\mathrm{a}}$

\begin{tabular}{lccc}
\hline & & \multicolumn{2}{c}{$\begin{array}{c}\text { Time until first twofold increase } \\
\text { over basal levels (min) }\end{array}$} \\
\cline { 3 - 4 } Transcript & Position in operon & In vitro & In planta \\
\hline hrpR & 1 of 1 & $<5$ & 5 to 10 \\
hrpL & 1 of 1 & 10 & 20 \\
hrpA & 1 of 1 & 10 & 20 to 40 \\
hrpZ & 1 of 1 & 10 to 20 & 20 to 40 \\
hrcC & 3 of 5 & 20 & 40 to 80 \\
hrpF & 1 of 5 & 20 & 20 to 40 \\
hrcJ & 1 of 3 & 20 & 20 \\
hrpP & 1 of 7 & 20 & 20 to 40 \\
hrpY & 1 of 1 & 20 & 20 to 40 \\
avrPphE & 1 of 1 & 20 & 20 to 40 \\
hrpJ & 1 of 5 & 40 & 40 to 80 \\
hrcN & 4 of 5 & 40 & 80 to 120 \\
virPphA & 1 of 1 & 40 to 80 & 40 to 80 \\
hrcU & 7 of 7 & 80 & 80 to 120 \\
\hline
\end{tabular}

${ }^{\text {a }}$ Basal level is defined as the level of transcription after washing bacteria in $10 \mathrm{mM} \mathrm{MgCl}$ before inoculation.

${ }^{\mathrm{b}}$ Data compiled from two repeated experiments using duplicate analyses at each time point.
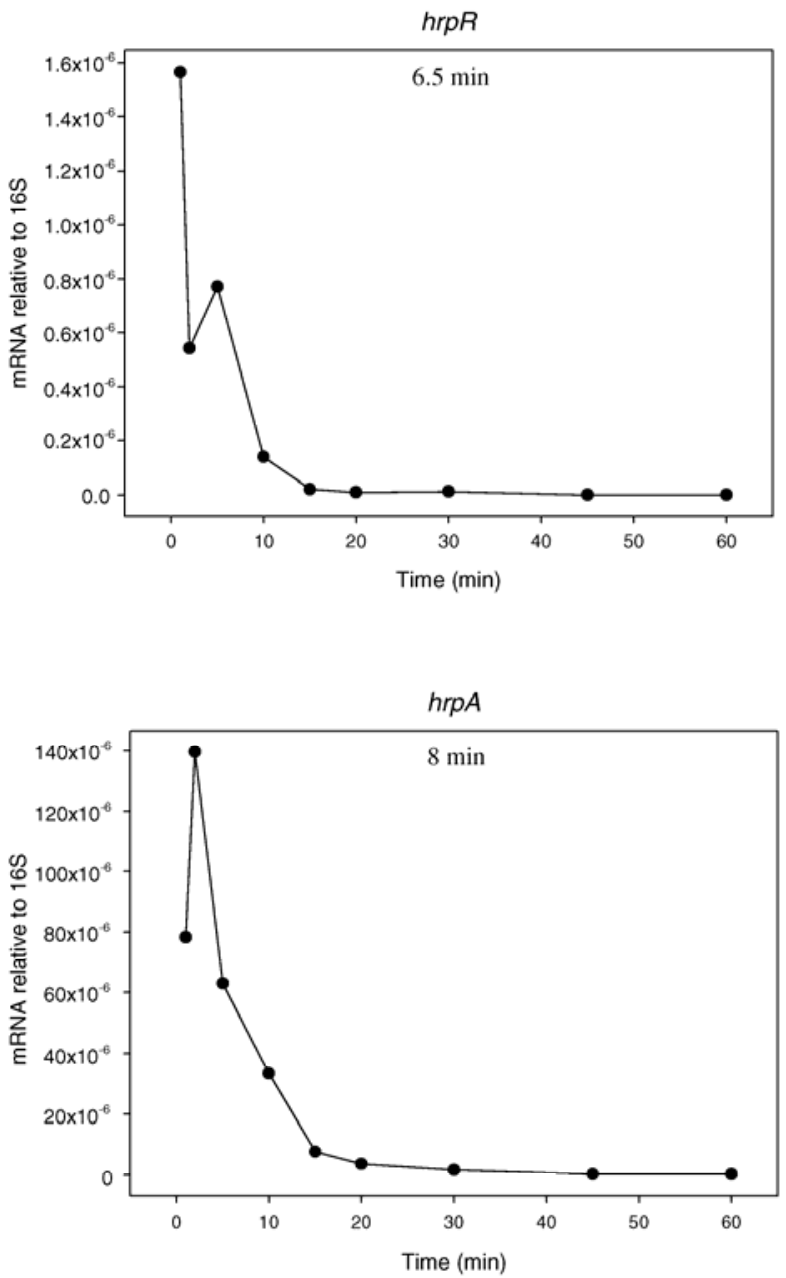

Regulation by HrpL has been linked to the presence of the hrp box motif upstream of hrp and effector genes (Fouts et al. 2002). There are variations in the region among the genes examined here. In particular, the motif found upstream of avrPphE is quite divergent from the general consensus but the effector is clearly regulated by HrpL. For virPphA, the second conserved motif is CCAA rather than the consensus CCAC. There is, however, no obvious link between patterns of gene expression observed and $h r p$ box sequence; for example, through the presence of 13,15 , or 16 nucleotides between the conserved GGAACC and CCAC motifs as listed in Table 3.

Two additional regulators of hrp gene expression reported in P. syringae are HrpV and Lon protease (Bretz et al. 2002; Preston et al. 1998). It is difficult to attribute the different patterns of expression we have observed to the action of either of these proteins. The Lon protease has been reported to act directly on HrpR protein and thereby provide a more general downregulation of $\mathrm{HrpL}$ and downstream gene expression. $\mathrm{HrpV}$ is thought to operate by reducing transcription of $h r p R$ and also would be expected to have a more general role. The involvement of $\mathrm{HrpV}$ in the fine tuning of early transcript accumulation also seems unlikely because it is the fifth gene of the $h r p F$ operon and $h r p F$ mRNA itself follows the most common pattern of $h r p$ transcript accumulation (Table 2).

The patterns of induction observed were significantly different in timing and quantity in the plant compared with in vitro. In particular, more rapid onset of transcript accumulation was found in vitro, but levels reached after $2 \mathrm{~h}$ typically were sev-
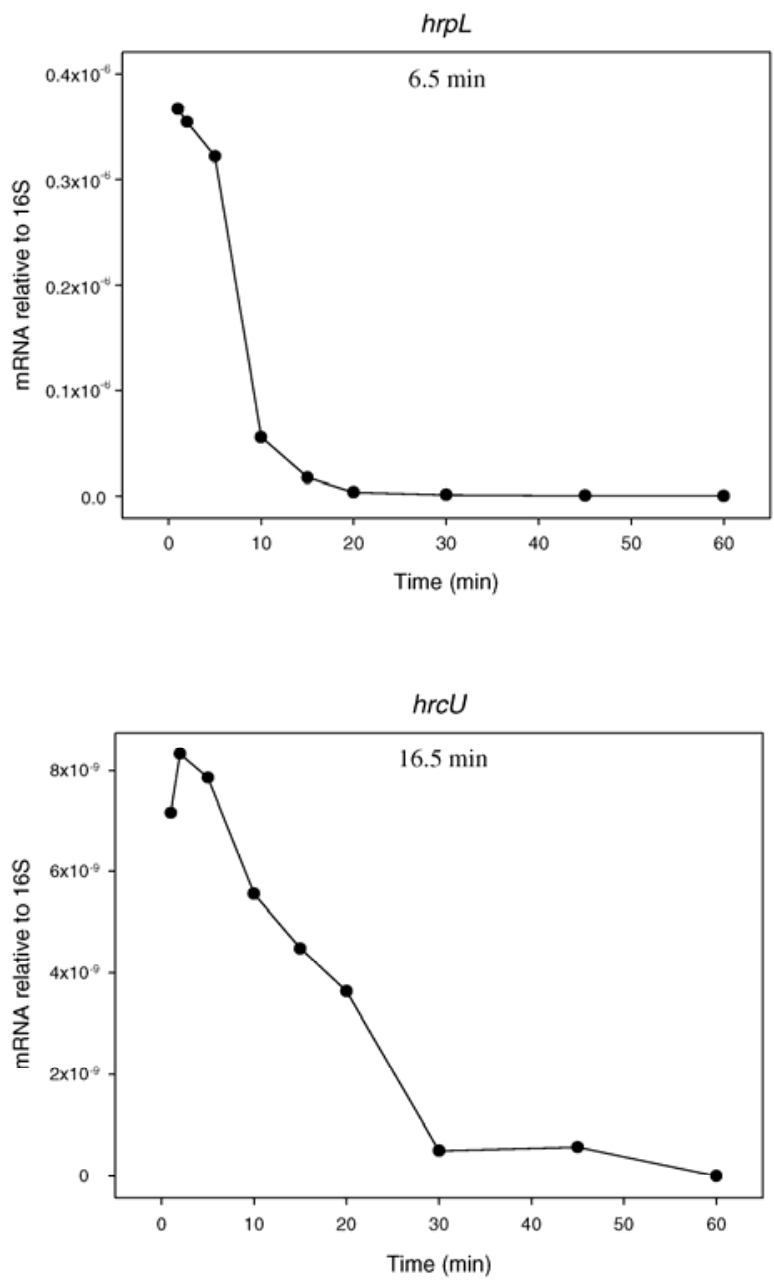

Fig. 4. Decay of mRNA in Pseudomonas syringae pv. phaseolicola race 7 strain $1449 \mathrm{~B}$ after the inhibition of transcription with rifampicin $\left(200 \mu \mathrm{mg} \mathrm{l}^{-1}\right)$, following a 2-h incubation in minimal medium. Half-lives were estimated to the nearest half-minute from the time that mRNA levels began to decay. Data for other genes examined are provided as supplemental material; results are from duplicate analyses. 
eral-fold greater in planta. In vitro, bacteria are exposed immediately to a stable inducing environment; whereas, in the plant, conditions are more dynamic. The $10-\mathrm{mM} \mathrm{MgCl}_{2}$ solution used to suspend bacteria for injection would be expected immediately to solubilize material from the apoplastic face of the plant cell wall. The solution is taken up by the transpiration stream as the inoculum effectively evaporates, so that no water-soaking is observed after approximately $30 \mathrm{~min}$. Bacteria are, therefore, deposited on the cell wall as the aqueous suspension dries out (Brown and Mansfield 1988). The conditions on the plant cell wall surface would appear to be highly inductive. Our results also suggest that that contact with the cell wall may itself enhance transcription of $h r p A$, $h r p Z$, and virPphA. Whether or not specific plant factors are required for the extremely rapid mRNA synthesis observed between 80 and $240 \mathrm{~min}$ in the plant (Fig. 3) remains to be determined. However, in a critical analysis of such factors it would be extremely difficult to mimic the in planta micro-environment, not only regarding nutritional status but also the purely physical conditions of life on the apoplastic face of the plant cell wall. The drop in transcript levels recorded between 4 and $24 \mathrm{~h}$ after inoculation into leaves indicates that neither the TTSS nor effectors are required for colonies to expand following the initial establishment of parasitism. The nutritional conditions established within colonized tissue may be equivalent to those found in suppressive rich media.

Transcription of flagellar genes is regulated in a strictly hierarchical fashion involving the sequential expression of three classes of transcript encoding activator, basal body, and filament components (Karlinsey et al. 2000; Kurtsukake et al. 1990; Soutourina and Bertin, 2003). Contrary to our original hypothesis, a similar synthetic hierarchy has not emerged from our experiments with the TTSS in $P$. syringae pv. phaseolicola. In the plant pathogen, it appears that genes encoding effector proteins secreted through the TTSS are expressed alongside (or before) those for core components of the secretion. Intuitively, one would expect levels of secreted proteins to be higher than those of membrane-anchored TTSS components. For example, numerous copies of extracellular HrpA are required to construct the Hrp pilus which must traverse the plant cell wall extending from a single-basal TTSS unit. The transcript levels recorded largely reflect the differential protein levels that would be expected despite all genes being regulated primarily by HrpL. For example, the abundance of RNA from hrpA, hrpZ, and virPphA is much greater than that of the core components $h r c C$, $h r c J$, and also $h r c U$, for which the slowest induction and lowest abundance was recorded. $h r c U$ encodes an inner membrane component of the TTSS and is the seventh open reading frame (ORF) within the $h r p P$ operon (Fig. 1). Irrespective of proposed function, mRNA from the first ORF of each $h r p$ operon typically accumulated more rapidly than those from downstream ORFs, as summarized in Table 2.

Protein expression may be regulated at the level of transcription or translation, and also by the rapidity with which mRNAs are degraded by endogenous RNAses. The $h r p A$ transcript of $P$. syringae pv. tomato strain DC3000, for example, appears to be stabilized by its $5^{\prime}$ untranslated RNA, without which production of the HrpA protein is greatly reduced (Hienonen et al. 2002). We tested the relative stability of hrp and effector gene transcripts in $P$. syringae pv. phaseolicola race 7 by measuring their abundance after RNA synthesis was arrested by rifampicin. Most previous studies on RNA stability in bacteria have been carried out on E. coli, where $80 \%$ of mRNAs can be expected to have a half-life of between 3 and 8 min (Bernstein et al. 2002). Almost all of the RNAs examined in this study had half-lives within this range, the only exception being $h r c U$, which had a half-life of $16.5 \mathrm{~min}$. The $h r c U$ coding region is located at the $3^{\prime}$ end of the hrpP operon (Fig. 1). Studies on E. coli (Selinger et al. 2003) and Acinetobacter calcoaceticus (Schirmer and Hillen 1998) have shown that RNA degradation is most likely to occur in the $5^{\prime}$ to $3^{\prime}$ direction. Therefore, the relatively long-lived $h r c U$ transcript may be well protected by RNA further toward the $5^{\prime}$ end of the operon. The stability of $h r c U$ RNA might compensate for its low abundance.

It is possible that high levels of expression of proteins such as $\mathrm{HrcU}$, which are targeted to membranes, might be harmful to bacteria. For example, overexpression of the $h r c C$ homologue in Xanthomonas spp. induces transcription of phageshock ( $p s p$ ) genes when expressed in E. coli (Wengelnik et al. 1996). Expression of the $p s p$ operon of $Y$. enterocolitica is also activated when a functional TTSS is present (Darwin and Miller 2001), perhaps to limit potential damage caused by TTSS membrane-spanning proteins.

Organization of the TTSS (like the flagellum) provides an excellent model for understanding regulation of cellular architecture within gram-negative bacteria. Real-time PCR has proved to be a sensitive means to examine gene expression within the host plant as well as in vitro. Application of the approach of quantitative analysis of gene expression that we have developed here should help to unravel the puzzle of how 30+ effector proteins might be delivered in a strict hierarchy through the Hrp pilus and into plant cells (Fouts et al. 2002). Regulation of effector delivery has been proposed to operate via protein chaperones (Guttman et al. 2002; Thomas and Finlay 2003), but the subtle transcriptional controls revealed by our experiments indicate that transcript abundance and stability may also have a key role in the establishment of parasitism by allowing the sequential and selective accumulation of the effector proteins that suppress plant defenses.

\section{MATERIALS AND METHODS}

\section{Preparation of inoculum.}

Rifampicin-resistant strains of $P$. syringae pv. phaseolicola isolates $1488 \mathrm{~A}$ (race 6) and $1449 \mathrm{~B}$ (race 7) were grown at $25^{\circ} \mathrm{C}$ overnight in LB medium (10 g liter ${ }^{-1}$ of tryptone, $5 \mathrm{~g} \mathrm{liter}^{-1}$ of yeast extract, $10 \mathrm{~g}$ liter $^{-1}$ of $\mathrm{NaCl}, \mathrm{pH}$ 7.0) containing rifampicin at $80 \mu \mathrm{g} \mathrm{ml}^{-1}$. Strain 1448A::143, a race 6 strain carrying

Table 3. Pseudomonas syringae pv. phaseolicola races 6 and 7 hrp box sequences, showing spacing between $5^{\prime}$ and $3^{\prime}$ conserved regions ${ }^{\text {a }}$

\begin{tabular}{|c|c|c|}
\hline Gene & hrp Box sequence & Spacing (nt) \\
\hline hrpA & GGAACCGATTTAAGGGTCGTTACCACCTA & 16 \\
\hline hrpF & GGAACCGCTCCAGCCGTTTGCTCCACTCA & 16 \\
\hline hrcJ & GGAACTTGGGCAGGATGTGCCACAAG & 13 \\
\hline hrpJ & GGAACCGAATCTTGGCCAGGCCCCACTCA & 16 \\
\hline hrpP & GGAACTGAAATCGATGCTCGACCACTTA & 15 \\
\hline hrpY & GGAACCAACTCGCACGCAAAACCACACA & 15 \\
\hline avrPphF & GGAACCAGCTACATAGGTATGACCACTGA & 16 \\
\hline virPphA & GGAACCACTTATGTCCGATCGCCAACTCA & 15 \\
\hline avrPphE & GCAACGCCGGTTATCGGCTGGGCCATCGA & 16 \\
\hline
\end{tabular}

${ }^{\text {a }}$ Conserved regions, according to Fouts et al. (2002), are marked in bold; $\mathrm{nt}=$ nucleotides. 
an insertional inactivation of hrpL (Mansfield et al. 1994) was grown overnight in LB supplemented with rifampicin at $80 \mu \mathrm{g}$ $\mathrm{ml}^{-1}$ and kanamycin at $40 \mu \mathrm{g} \mathrm{ml}^{-1}$. Cells were washed twice in $10 \mathrm{mM} \mathrm{MgCl} 2$ and adjusted to an optical density at $600 \mathrm{~nm}$ of 0.6 (corresponding to an approximate concentration of $5 \times 10^{8}$ $\left.\mathrm{CFU} \mathrm{ml} \mathrm{m}^{-1}\right)$.

\section{In vitro induction.}

After quantification, $100 \mathrm{ml}$ of washed cell suspension was centrifuged and resuspended in $100 \mathrm{ml}$ of minimal medium, pH 7.0 (Huyhn et al. 1989) containing $10 \mathrm{mM}$ fructose, prewarmed to $25^{\circ} \mathrm{C}$. Minimal medium cultures were shaken at $25^{\circ} \mathrm{C}$ and $0.5-\mathrm{ml}$ aliquots removed, usually after $5,10,20,40$, 80 , and $120 \mathrm{~min}$. Samples were also taken from LB cultures before washing and from the second $\mathrm{MgCl}_{2}$ wash. Samples were mixed immediately with $1 \mathrm{ml}$ of RNA protect reagent (Qiagen, Crawley, U.K.) to arrest RNA synthesis and degradation, incubated at room temperature for $5 \mathrm{~min}$, and pelleted at $5,000 \times g$ for $10 \mathrm{~min}$. Pellets were frozen at $-70^{\circ} \mathrm{C}$ until RNA extraction was performed. Prior to RNA extraction, pellets were resuspended in $100 \mu$ of Tris-EDTA (TE) containing 80 $\mu \mathrm{g}$ of lysozyme (Sigma, Poole, U.K.) and incubated for $10 \mathrm{~min}$ at room temperature.

\section{Bean inoculations.}

French bean plants (Phaseolus vulgaris L. cv. Canadian Wonder) were inoculated with bacterial suspensions (prepared as above) as previously described (Harper et al. 1987), taking care to remove any bacterial suspension adhering to the outer surfaces of the leaves. Plants were maintained at $25^{\circ} \mathrm{C}$ throughout the course of the experiment and samples were usually taken at intervals of $5,10,20,40,80,120,240$, and 1,440 min after inoculation.

\section{Extraction of total bacterial RNA from inoculated leaves.}

Discs, approximately $9 \mathrm{~mm}$ in diameter, were cut from inoculation sites in leaves and frozen immediately in liquid $\mathrm{N}_{2}$. Two discs were macerated in $500 \mu \mathrm{l}$ of $1 \times$ RNA protect reagent (Qiagen), incubated at room temperature, and centrifuged at $5,000 \times g$ for $10 \mathrm{~min}$. Pellets were resuspended in $100 \mu \mathrm{TE}$ containing $100 \mu \mathrm{g}$ of lysozyme (Sigma) and incubated at room temperature for $10 \mathrm{~min}$. RNA was extracted immediately from lysates as described below.

\section{Fractionation of attached and unattached bacteria from inoculated leaves.}

Discs were cut from leaves, frozen, macerated, and incubated in RNA protect reagent as described above. The resulting suspensions then were spun through $10-\mu \mathrm{m}$ filters (VectaSpin Micro, Whatman, Maidstone, U.K.) for $30 \mathrm{~s}$ at $1,000 \times g$. The filtrate (containing bacteria not attached to leaf tissue) was spun for a further $10 \mathrm{~min}$ at $5,000 \times g$ and the resulting pellet resuspended in $100 \mu \mathrm{l}$ of TE containing $100 \mu \mathrm{g}$ of lysozyme (Sigma) and incubated at room temperature for $10 \mathrm{~min}$. The filter residue (containing plant debris and attached bacteria) was mixed with $100 \mu \mathrm{l}$ of TE-lysozyme mix as above, incubated for $10 \mathrm{~min}$ at room temperature, and spun again through the filter for $30 \mathrm{~s}$ at $1,000 \times g$. The resulting filtrate contained predominately RNA released from bacteria attached to plant material. RNA was extracted immediately from lysates as described below.

\section{Stability of mRNAs in vitro.}

The rifampicin-sensitive wild-type race 7 strain 1449B was grown overnight in LB, washed, and transferred to minimal medium, $\mathrm{pH} 7.0$, containing $10 \mathrm{mM}$ fructose as described above. Induction of TTSS genes was allowed to proceed for 2 $\mathrm{h}$, during which samples were taken as described above for in vitro induction. RNA transcription then was arrested by addition of rifampicin to a final concentration of $200 \mu \mathrm{g} \mathrm{ml}^{-1}$ and, after a further $1,2,5,10,15,20,30,45$, and $60 \mathrm{~min}, 0.5-\mathrm{ml}$ aliquots were mixed with $1 \mathrm{ml}$ of RNA protect reagent and prepared for RNA extraction as described above.

\section{Isolation of nucleic acids.}

Genomic DNA was isolated from strains of $P$. syringae pv. phaseolicola as previously described (Thwaites et al. 1999). Plasmid DNA was isolated from $E$. coli strains using the Qiagen plasmid mini kit (Qiagen). RNA was isolated from cell lysates using the RNeasy bacteria mini kit, using the on-column DNase kit (Qiagen) to remove contaminating DNA. RNAs were eluted in either $100 \mu \mathrm{l}$ (in vitro inductions) or $30 \mu \mathrm{l}$ (in planta inductions) of sterile water and were treated a second time with DNase (Promega, Southampton, U.K.) in order to ensure complete removal of genomic DNA.

\section{Synthesis and testing of cDNAs.}

RNA from cells induced in vitro was quantified by spectrophotometry and $2 \mu \mathrm{g}$ of RNA was used for each cDNA synthesis. RNA levels obtained from in planta samples were too low to be reliably measured by this method; therefore, in these cases, the whole RNA extract was used for cDNA synthesis. cDNAs were synthesized using the Omniscript reverse transcriptase system (Qiagen) with either a mixture of oligonucleotide primers specific to the target genes (reverse primers used for cloning targets listed in Table 4) or random hexanu-

Table 4. Primers for real-time polymerase chain reaction (PCR) experiments: sequences are quoted $5^{\prime}$ to $3^{\prime}$

\begin{tabular}{|c|c|c|c|c|c|}
\hline \multirow[b]{2}{*}{ Target } & \multicolumn{2}{|c|}{ Primers for cloning targets } & \multicolumn{3}{|c|}{ Primers and probes for TaqMan real-time PCR } \\
\hline & Forward & Reverse & Forward primer & Reverse primer & Probe \\
\hline hrpA & tcatgagttctctgactaacgcg & actggacgaccgagttccgg & cagggtatcaacagcgtcaaga & gctacccgtgtttttggtcagt & cagcgccgaccgcaaca \\
\hline $\operatorname{hrcC}$ & cgcctgatcggtgatcaggtca & gagcagtgatggecgactctct & gcgaaacactgccatttgaaa & acaaccgcaacacccaat & cccgcgeccggatcacaaa \\
\hline$h r p F$ & cgacagcacgctgaatcgc & gcggatcaatggcgaagg & agggtggcaacggacattt & cgatgacatttttggtcattttgt & tccaacatcgetgaccagtgcca \\
\hline$h r c J$ & gtcgcagatagacggtgtcatc & gcgactccgegcgccgaac & cgcggecgtattcatca & tttcttcgattctgccgattg & cactcggctgcgetggaccc \\
\hline hrpJ & cacgtggtgctgcaagcggc & agcaggtgttcacaaccgcgc & gctcacccaaacgctgaaac & cgccetggcagtattaatgc & cgcaagttcggaccacacgcc \\
\hline hrpL & gtaatgaacccggatgatgtcg & ccegtgcccgggacagtcg & gcgcaacgagcacaagttt & ggttcaacgcaataccacacaa & acatgccagcaagccgcagacc \\
\hline$h r c N$ & ggaaagacgcccacgcagcacg & gcaaaagcaccgaggcaatcacc & gccaaggtgggcgatctt & attcctgagtgaaaccgacgatt & ctgccgtcggetttgctcacet \\
\hline hrpP & acacagccttctgcgeccgc & tcagaacgtcgcgacgggcga & tgatacctcaggtcggtgaagag & gggagggcgatgctgc & tcagcaaggtttcggcggc \\
\hline hrpR & ggtaaagacaccetggccaatcg & tgttccaccagttcatccagaggg & cccgaatcgttggcagaa & cgagcgcggcagaca & tgcgccattgacgacaccgaataa \\
\hline$h r c U$ & cagtccgaaggcgatcctcatg & ctcaacctgaatcacttcatcgg & ggcettgaagctggacatca & ttctgcccggaaaacatctg & aagatcaaccecttctcgcatgccaa \\
\hline hrpY & cgttcgcaacttcagcgaggg & ggacgcetcgcgacccatc & gagtctctgcaaaccgcagataa & actctcacgctcaccattaacga & atcagcgggcagcacgctttcat \\
\hline hrpZ & tgggcagtcaacagaatgcagc & cagcagcatgttgaccagcagc & atccgcttatcgacgctaacac & gtctatcagctcaccgatcaactg & cccgccagcaacagcaattcca \\
\hline virPphA & cgcaatacgettgcgtagactg & caagcctttgtctgttcagcgg & tccacaatttagtcaattgcgtaca & cgcatctctgaaacccaactc & tctcgaaagcagatgctgaatctga \\
\hline avrPphE & cgcgecaggccetagcgt & cggcgtgcttcacgcaacgc & cctagcgtggaaaccactgaa & cgttctgtttgtgaactgcaaga & atcatcggeccagaacccegc \\
\hline avrPphF & ggaaccagctacataggtatgac & ggatcaatggctgttcagaccg & ggggactccatgaagaattcg & aggaaaccaggcatcccata & ccgcttaatcgatgggetcgca \\
\hline $16 S^{1}$ & cgggtacttgtacctggtggc & cttgccagttttggatgcagttc & caatgggcgaaagcctgat & agtgctttacaatccgaagacctt & agccatgccgcgtgtgtga \\
\hline
\end{tabular}


cleotides (Promega). After synthesis, cDNAs were diluted 1:20 in TE and tested by PCR using a selection of primers listed in Table 4. An aliquot of RNA was also tested by PCR to ensure that no trace of contaminating genomic DNA was detectable.

\section{PCR reactions.}

All PCR reactions were carried out in 15- $\mu$ l volumes containing $1 \times$ PCR buffer $\left(16 \mathrm{mM}\left(\mathrm{NH}_{4}\right)_{2} \mathrm{SO}_{4}, 67 \mathrm{mM}\right.$ Tris- $\mathrm{HCl}[\mathrm{pH}$ 8.8], $0.01 \%$ Tween-20), $1.5 \mathrm{mM} \mathrm{MgSO}{ }_{4}, 200 \mu \mathrm{M}$ each dNTP, 1 $\mu \mathrm{M}$ each primer, and 1.5 units of Taq DNA polymerase. PCR cycling was performed in a Perkin-Elmer 9700 thermocycler using the following program: $95^{\circ} \mathrm{C}$ for $30 \mathrm{~s}$ followed by $30 \mathrm{cy}$ cles of 94,55 , and $72^{\circ} \mathrm{C}$ for $30 \mathrm{~s}$ each. Reaction products were visualized on ethidium bromide-stained agarose gels.

\section{DNA sequencing.}

Sequences upstream of a selection of target genes were amplified with the following primers (forward/reverse primers, $5^{\prime}$ to $\left.3^{\prime}\right)$ : $h r p A$ (tggagttggacatgccacgc/ctcttgacgctgttgataccctgc), hrpF (gcctgcgtctgagcgatgcc/caagcacgtcatccacgtcgg), hrcJ (ctg ctgcctgactgataccc/gcaccgcttgaaacattatccg), hrpJ (ctatagcgataac cgtgccagcc/gcgaatcggcgtgaccgtgtgg), hrpP (cactggaagacgatcc gcagcg/gccatcggtcgatatcgttcgg), hrp $Y$ (ggatacggcgaacacgctagg c/ctcagcagccagttcgccagagg), hrpZ (gaccgcaacattgcactgacc/acg accgagttccggatcttgc), avrPphE (cattgattgacagtgacgagagcg/ctg tttgtgaactgcaagaagcg), and virPphA (catatgcagctgagtcaaacag c/gatggtcctgctccgttgatacc). PCR products were purified from agarose gels with the min-elute gel purification kit (Qiagen) and cloned using the pGEM-T easy PCR cloning system (Promega). Plasmid clones were sequenced using the BigDye cycle sequencing kit and an ABI310 sequence analyzer (ABI, Warrington, U.K.).

\section{TaqMan real-time PCR.}

All targets genes for real-time PCR analysis were amplified using the primers given in Table 4. Reaction products were purified using the min-elute PCR purification kit (Qiagen) and cloned using the pGEM-T Easy PCR cloning system (Promega). Plasmid clones of all targets were quantified by spectrophotometry for use as quantitative standards in real-time PCR.

TaqMan PCR reactions were performed in $25-\mu$ l volumes containing $12.5 \mu \mathrm{l}$ of qPCR Mastermix Plus solution (consisting of thermostable polymerase, buffers, and reference dye) (Eurogentec, Romsey, U.K.), $100 \mathrm{nM}$ forward and reverse primers, $300 \mathrm{nM}$ double-labeled oligonucleotide probe, and 5 $\mu \mathrm{l}$ of cDNA template. Oligonucleotide probes were labeled with FAM and ELLE dyes at the $5^{\prime}$ and $3^{\prime}$ ends, respectively. Sequences of TaqMan primers and probes (purchased from Oswel/Eurogentec, Romsey, U.K.) are given in Table 4. Primers were designed to yield reaction products of between 70 and $120 \mathrm{bp}$ in length. PCR amplification was as follows: 2 min at $50^{\circ} \mathrm{C}, 10 \mathrm{~min}$ at $95^{\circ} \mathrm{C}$, and 40 cycles of $95^{\circ} \mathrm{C}(15 \mathrm{~s})$ and $60^{\circ} \mathrm{C}$ (1 min). Reactions were run in an ABI PRISM 7700 sequence detection system and data were collected at all isothermal stages. Following PCR amplification, threshold detection parameters (baseline and cycle threshold limit) were adjusted manually to optimize the results relative to standard curves which were linear over the concentrations tested, obtained by amplification of four 10-fold dilutions of clones of all target sequences. Duplicate samples were quantified for each transcript and mean values used to express mRNA abundance relative to $16 \mathrm{~S}$ RNA.

\section{ACKNOWLEDGMENTS}

We wish to acknowledge financial support from the U.K. BBSRC and EC Framework IV grant BIO-CT97-2244.

\section{LITERATURE CITED}

Aldon, D., Brito, B., Boucher, C., and Genin, S. 2000. A bacterial sensor of plant cell contact controls the transcriptional induction of Ralstonia solanacearum pathogenicity genes. EMBO (Eur. Mol. Biol. Organ.) J. 19:2304-2314.

Bernstein, J. A., Khodursky, A. B., Lin, P.-H., Lin-Chao, S., and Cohen, S. 2002. Global analysis of mRNA decay and abundance in Escherichia coli at single-gene resolution using two-color fluorescent DNA microarrays. Proc. Natl. Acad. Sci. U.S.A. 99:9697-9702.

Blocker, A., Komoriya, K., and Aizawa, S. 2003. Type III secretion systems and bacterial flagella: insights into their function from structural similarities. Proc. Natl. Acad. Sci. U.S.A. 100:3027-3030.

Bogdanove, A. J., Beer, S. V., Bonas, U., Boucher, C. A., Collmer, A., Coplin, D. L, Cornelis, G. R, Huang, H. C., Hutcheson, S. W. Panopoulos, N. J., and Van Gijsegem, F. 1996. Unified nomenclature for broadly conserved hrp genes of phytopathogenic bacteria. Mol. Microbiol. 20:681-683.

Bretz, J., Losada, L., Lisboa, K., and Hutcheson, S. W. 2002. Lon protease functions as a negative regulator of type III protein secretion in Pseudomonas syringae. Mol. Microbiol. 45:397-409.

Brown, I. R., and Mansfield, J. W. 1988. An ultrastructural study including cytochemistry and quantitative analysis of the interactions between pseudomonads and leaves of Phaseolus vulgaris L. Physiol. Mol. Plant. Pathol. 33:351-376.

Bustin, S. A. 2002. Quantification of mRNA using real-time reverse transcription PCR (RT-PCR): trends and problems. J. Mol. Endocrinol 29:23-29.

Collmer, A., Lindeberg, M., Petnicki-Ocwieja, T., Schneider, D. J., and Alfano, J. R. 2002. Genomic mining type III secretion system effectors in Pseudomonas syringae yields new picks for all TTSS prospectors. Trends Microbiol. 10:462-469.

Cornelis, G. R., and Van Gijsegem, F. 2000. Assembly and function of type III secretory systems. Annu. Rev. Microbiol. 54:735-774.

Darwin, A. J., and Miller, V. J. 2001. The psp locus of Yersinia enterocolitica is required for virulence and for growth in vitro when the Ysc type III secretion system is produced. Mol. Microbiol. 39:429-444.

Fouts, D. E., Abramovitch, R. B., Alfano, J. R., Baldo, A. M., Buell, C. R., Cartinhour, S., Chatterjee, A. K., D'Ascenzo, M., Gwinn, M. L. Lazarowitz, S. G., Lin, N. C., Martin, G. B., Rehm, A. H., Schneider, D. H., van Dijk, K., Tang, X., and Collmer, A. 2002. Genomewide identification of Pseudomonas syringae pv. tomato DC3000 promoters controlled by the HrpL alternative sigma factor. Proc. Natl. Acad. Sci. U.S.A. 99:2275-2280.

Grimm, C., Aufsatz, W., and Panopoulos, N. J. 1995. The hrpRS locus of Pseudomonas syringae pv. phaseolicola constitutes a complex regulatory unit. Mol. Microbiol. 15:155-165.

Guttman, D. S., Vinatzer, B. A., Sarkar, S. F., Ranall, M. V., Kettler, G., and Greenberg, J. T. 2002. A functional screen for the type III (Hrp) secretome of the plant pathogen Pseudomonas syringae. Science 295:1722-1726.

Harper, S., Zewdie, N., Brown, I. R., and Mansfield, J. W. 1987. Histological, physiological and genetical studies of the responses of leaves and pods of Phaseolus vulgaris to three races of Pseudomonas syringae pv. phaseolicola and Pseudomonas syringae pv. coronafaciens. Physiol. Mol. Plant Pathol. 31:153-172.

He, S. Y. 1997. Hrp-controlled interkingdom protein transport: learning from flagellar assembly? Trends Microbiol. 5:489-495.

Hienonen, E., Roine, E., Romantschuk, M., and Taira, S. 2002. mRNA stability and the secretion signal of $h r p A$, a pilin secreted by the type III system in Pseudomonas syringae. Mol. Gen. Genet. 266:973-978.

Huynh, T. V., Dahlbeck, D., and Staskawicz, B. J. 1989. Bacterial blight of soybean: regulation of a pathogen gene determining host cultivar specificity. Science 245:1374-1377.

Jackson, R. W., Athanassopoulos, E., Tsiamis, G., Mansfield, J. W., Sesma, A., Arnold, D. L, Gibbon, M. J., Murillo, J., Taylor, J. D., and Vivian, A. 1999. Identification of a pathogenicity island, which contains genes for virulence and avirulence, on a large native plasmid in the bean pathogen Pseudomonas syringae pathovar phaseolicola. Proc. Natl. Acad. Sci. U.S.A. 96:10875-10880.

Jin, Q., and He, S. Y. 2001. The Hrp pilus: a conduit for type III secretion in Pseudomonas syringae. Science 294:2556-2558.

Jin, Q., Thilmony, R., Zwiesler-Vollick, J., and He, S. Y. 2003. Type III protein secretion in Pseudomonas syringae. Microbes Infect. 5:301-10.

Karlinsey, J. E., Lonner, J., Brown, K. L., and Hughes, K. T. 2000. Translation/secretion coupling by type III secretion systems. Cell 102:487-497.

Kurtsukake, K., Ohya, Y., and Lino, T. 1990. Transcriptional analysis of the flagellar regulon of Salmonella typhimurium. J. Bacteriol. 172:741-747.

Lee, J., Klusener, B., Tsiamis, G., Stevens, C., Neyt, C., Tampakaki, A. P., Panopoulos, N. J., Noller, J., Weiler, E. W., Cornelis, G. R., Mansfield, 
J. W., and Nurnberger, T. 2001. HrpZ(Psph) from the plant pathogen Pseudomonas syringae pv. phaseolicola binds to lipid bilayers and forms an ion-conducting pore in vitro. Proc. Natl. Acad. Sci. U.S.A. 98:289-294

Li, C. M., Brown, I., Mansfield, J., Stevens, C., Boureau, T., Romantschuk, M., and Taira, S. 2002. The Hrp pilus of Pseudomonas syringae elongates from its tip and acts as a conduit for translocation of the effector protein HrpZ. EMBO (Eur. Mol. Biol. Organ.) J. 21:19091915.

Lindgren, P. B. 1997. The role of hrp genes during plant-bacterial interactions. Annu. Rev. Phytopathol. 35:129-152.

Lindgren, P. B., Peet, R. C., and Panopoulos, N. J. 1986. Gene cluster of Pseudomonas syringae pv. 'phaseolicola' controls pathogenicity of bean plants and hypersensitivity on nonhost plants. J. Bacteriol. 168:512-522.

Mansfield, J., Jenner, C., Hockenhull, R., Bennett, M., and Stewart, R. 1994. Characterization of avrPphE, a gene for cultivar specific avirulence from Pseudomonas syringae pv. phaseolicola which is physically linked to $h r p Y$, a new $h r p$ gene identified in the halo-blight bacterium. Mol. Plant-Microbe Interact. 7:726-739.

Marenda, M., Brito, B., Callard, D., Genin, S., Barberis, P., Boucher, C. and Arlat, M. 1998. PrhA controls a novel regulatory pathway required for the specific induction of Ralstonia solanacearum hrp genes in the presence of plant cells. Mol. Microbiol. 27:437-453.

Nizan-Koren, R.; Manulis, S., Mor, H., Iraki, N. M., and Barash, I. 2003. The regulatory cascade that activates the Hrp regulon in Erwinia herbicola pv. gypsophilae. Mol. Plant Microbe Interact. 16:249-260.

Preston, G., Huang, H. C., He, S. Y., and Collmer, A. 1995. The HrpZ proteins of Pseudomonas syringae pvs. syringae, glycinea, and tomato are encoded by an operon containing Yersinia ysc homologs and elicit the hypersensitive response in tomato but not soybean. Mol. Plant-Microbe Interact. 8:717-732.

Preston, G., Deng, W. L., Huang, H. C., and Collmer, A. 1998. Negative regulation of hrp genes in Pseudomonas syringae by HrpV. J. Bacteriol. 180: 4532-4537.

Rahme, L. G., Mindrinos, M. N., and Panopoulos, N. J. 1992. Plant and environmental sensory signals control the expression of hrp genes in Pseudomonas syringae pv. phaseolicola. J. Bacteriol. 174:3499-3507.
Schirmer, F., and Hillen, W. 1998. The Acinetobacter calcoaceticus NCIB8250 mop operon mRNA is differently degraded, resulting in a higher level of the $3^{\prime}$ CatA-encoding segment than of the $5^{\prime}$ phenolhydroxylase-encoding portion. Mol. Gen. Genet. 257:330-337.

Selinger, D. W., Saxena, R. M., Cheung, K. J., Church, G. M., and Rosenow, C. 2003. Global RNA half-life analysis in Escherichia coli reveals positional patterns of transcript degradation. Genome Res. 13:216-223.

Soutourina, O. A., and Bertin, P. N. 2003. Regulation cascade of flagellar expression in Gram-negative bacteria. FEMS (Fed. Eur. Microbiol. Soc.) Microbiol. Rev. 27:505-523.

Thomas, N. A., and Finlay, B. B. 2003. Establishing order for type III secretion substrates - a hierarchical process. Trends Microbiol. 11:398-403.

Thwaites, R., Mansfield, J., Eden-Green, S., and Seal, S. 1999. RAPD and rep PCR-based fingerprinting of vascular bacterial pathogens of Musa spp. Plant Pathol. 48:121-128.

Tsiamis, G., Mansfield, J. W., Hockenhull, R., Jackson, R. W., Sesma, A., Athanassopoulos, E., Bennett, M. A., Stevens, C., Vivian, A., Taylor, J. D., and Murillo, J. 2000. Cultivar-specific avirulence and virulence functions assigned to avrPphF in Pseudomonas syringae pv. phaseolicola the cause of bean halo-blight disease. EMBO (Eur. Mol Biol. Organ.) J. 19:3204-3214.

Van Gijsegem, F. 1997 In-planta regulation of phytopathogenic bacteria virulence genes: relevance of plant-derived signals. Eur. J. Plant Pathol. 103:291-301.

Wengelnik, K., Marie, C., Russel, M., and Bonas, U. 1996. Expression and localization of HrpA1, a protein of Xanthomonas campestris pv. vesicatoria essential for pathogenicity and induction of the hypersensitive reaction. J. Bacteriol. 178:1061-1069.

Xiao, Y., and Hutcheson, S. 1994. A single promoter sequence recognized by a newly identified alternate sigma factor directs expression of pathogenicity and host range determinants in Pseudomonas syringae. J. Bacteriol. 176:3089-3091.

Zwiesler-Vollick, J., Plovanich-Jones, A., Nomura, K., Bandyopadhyay, S., Joardar, V., Kunkel, B. N., and He, S. Y. 2002. Identification of novel hrp-regulated genes through functional genomic analysis of the Pseudomonas syringae pv. syringae DC3000 genome. Mol. Microbiol. 45:1207-1218. 